IZA DP No. 4552

Adolescent Motherhood and Secondary Schooling in Chile

Diana I. Kruger

Matias Berthelon

Rodrigo Navia

November 2009 


\title{
Adolescent Motherhood and Secondary Schooling in Chile
}

\author{
Diana I. Kruger \\ Catholic University of Valparaiso \\ and IZA \\ Matias Berthelon \\ Catholic University of Valparaiso \\ Rodrigo Navia \\ Catholic University of Valparaiso
}
Discussion Paper No. 4552
November 2009

\author{
IZA \\ P.O. Box 7240 \\ 53072 Bonn \\ Germany \\ Phone: +49-228-3894-0 \\ Fax: +49-228-3894-180 \\ E-mail: iza@iza.org
}

\begin{abstract}
Any opinions expressed here are those of the author(s) and not those of IZA. Research published in this series may include views on policy, but the institute itself takes no institutional policy positions.

The Institute for the Study of Labor (IZA) in Bonn is a local and virtual international research center and a place of communication between science, politics and business. IZA is an independent nonprofit organization supported by Deutsche Post Foundation. The center is associated with the University of Bonn and offers a stimulating research environment through its international network, workshops and conferences, data service, project support, research visits and doctoral program. IZA engages in (i) original and internationally competitive research in all fields of labor economics, (ii) development of policy concepts, and (iii) dissemination of research results and concepts to the interested public.
\end{abstract}

IZA Discussion Papers often represent preliminary work and are circulated to encourage discussion. Citation of such a paper should account for its provisional character. A revised version may be available directly from the author. 
IZA Discussion Paper No. 4552

November 2009

\section{ABSTRACT}

\section{Adolescent Motherhood and Secondary Schooling in Chile*}

We analyze the determinants of adolescent motherhood and its subsequent effect on high school attendance and completion in Chile. Using eight rounds of household surveys, we find that adolescents who were born to teen mothers, those that live in poor households and in single-mother families, are more likely to have children, while access to full-time high schools reduces the likelihood of motherhood. We then estimate the effect of adolescent motherhood on the probability of high school attendance and completion. Using an instrumental variables approach to control for possible endogeneity between teen pregnancy and schooling, we find that being a mother reduces the probability of high school attendance and completion by 24 to 37 percent, making it the most important determinant of high school desertion, which implies that policies aimed at reducing early childbearing will have immediate, important effects on their school attainments.

JEL Classification: J13, O12, O15

Keywords: adolescent motherhood, high school completion, high school desertion, Chile

Corresponding author:

Diana I. Kruger

Catholic University of Valparaiso

School of Business Administration

Ave. Brasil 2830, Piso 7

Valparaíso

Chile

E-mail: diana.kruger@ucv.cl

\footnotetext{
* The authors received financial support from Chile's Comisión Nacional de Investigación Científica y Tecnológica (CONICYT), through FONDECYT Project No.1070447.
} 


\section{Introduction}

The relationship between adolescent fertility and a woman's future human capital (HC) outcomes has been analyzed by sociologists and economists for decades. ${ }^{1}$ Early studies analyzing the effects of teenage childbearing found that it has negative impacts on women's outcomes such as educational attainment, various labor market outcomes, incidence of poverty, single motherhood, and dependence on state welfare programs.

However, some of the results of the early findings were challenged on methodological grounds: teens who become mothers are different than those who delay childbirth in both observable and unobservable characteristics, so that the differences in their adult economic outcomes are not necessarily due to the young age of their first birth but to unmeasured variables. $^{2}$ Some identification strategies that have been implemented to address the problem include comparison of sisters’ outcomes (Geronimus and Korenman, 1992, 1993; Hoffman et al. 1993); comparing outcomes of teens who gave birth to twins vs. singleton births (Grogger and Bronars, 1993), natural experiments such as miscarriages (Hotz, McElroy and Sanders, 2005; Ashcraft and Lang, 2006; Fletcher and Wolfe, 2008), and matching based on observables (Levine and Painter, 2003). Most studies that applied the identification strategies mentioned above found that OLS over-stated the effects of teenage childbearing on HC outcomes but that the effects are not zero. ${ }^{3}$ And although the methodological debate is far from over, recent findings confirm that giving birth as an adolescent has negative effects on high school completion, years of schooling, and income and that it increases the likelihood of participating in public poverty assistance programs (Fletcher and Wolfe, 2008).

\footnotetext{
${ }^{1}$ Most of the literature has focused on U.S. data due to data availability, and to the fact that it is the OECD country with the highest rate of teen pregnancy: 54 per 1,000 women aged 15-19 years, followed by Great Britain, with 28 births per 1,000 adolescent women (Muñoz 2005.)

${ }^{2}$ For a clear summary of the methodological issues, see Hoffman 1998.

${ }^{3}$ The exception is the controversial paper by Hotz et al. (2005), which finds slightly better adult outcomes among women who became mothers as teens relative to those that miscarried; however, these results have been challenged due to small sample size (Hoffman, 1998).
} 
Studies that estimate the effects of early childbearing on women's schooling and future socio-economic outcomes in Latin American countries is scarce, despite the fact that it is an issue of serious public policy concern. ${ }^{4}$ In an international survey of 43 developing countries during the 1990s, Singh (1998) finds that large and steady declines in adolescent childbearing occurred in North and sub-Saharan Africa and Asia, and that despite increasing coverage of secondary education, in Latin America the declines have been small and some countries experienced increases in teenage childbearing.

This paper aims to contribute to the literature by estimating the causal effects of adolescent childbearing on young women's education outcomes in a developing country setting. Chile has gained international recognition for important reductions in poverty since 1990, and for large increases in education coverage: practically $100 \%$ of primary school-aged children attend school, while almost $90 \%$ of adolescents attend high-school. Nonetheless, high school desertion rates remain high among older teens and among lower-income youths. A recent study revealed that almost one third of teens aged 18-19 years did not attend high school (MIDEPLAN, 2003), and among girls aged 14 to 19 , the most cited reason for not attending high school was maternity or pregnancy. ${ }^{5}$

In this study, we estimate the effects of adolescent motherhood on high school completion first by OLS to construct a baseline measure, and we then address the identification issues discussed above with instrumental variables. Our baseline (OLS) estimations reveal that being a teenage mother reduces the probability of high school attendance/completion by 37 percent, while the I.V. estimations find that teenage childbearing reduces high school attainment by 24 percent. Similar to other studies in the literature, our OLS results over-estimate the impact of child bearing on schooling, yet when endogeneity is addressed the effect remains significantly

\footnotetext{
${ }^{4}$ An exception is Buvinic (1998).

${ }^{5} 24 \%$ of valid responses cited maternity or pregnancy as the reason for not attending high school, while 18 percent cited employment (authors’ estimates based on Chile’s national household survey (CASEN) 2006).
} 
different from zero—in fact, it is the most important determinant of high school desertion among adolescent girls in Chile. Our findings imply that policies aimed at reducing early childbearing will have an immediate positive impact on women's school attainment, which will undoubtedly improve labor market and income generating opportunities in their young adulthood.

This paper is organized as follows. Section 2 of this paper contains background information regarding recent trends in teenage births and high school completion in Chile. In section 3 we describe our empirical strategy, data, and variables constructed; section 4 presents our empirical findings regarding the determinants of adolescent motherhood, while section 5 discusses results of the effect of motherhood on high school attendance and completion. We close the paper with a section of concluding comments and policy implications.

\section{Adolescent motherhood and schooling in Chile}

Chile has made advances regarding secondary school attendance and completion. During the 1990-2006 period, the rate of high school attendance and completion among adolescent girls increased from 75 to 87 percent, respectively (Table 1). This can be attributed to large increases in educational investment and to compensatory programs targeted at the more vulnerable population. ${ }^{6}$

\section{[TABLE 1 HERE]}

Over the same period, however, the proportion of girls aged 15 to 19 that are mothers followed a different trend (Table 1). Between 1990 and 2000, the rate of teenage motherhood increased from 10 to 14 percent--a relative increase of 40 percent-followed by a rapid decline to 9.5 percent by 2006 .

\footnotetext{
${ }^{6}$ Source: World Bank (2006). Total educational expenditure increased from 4 to 7.6 percent of GDP between 1990 and 2002.
} 
What have been the determinants of teen births in Chile, and to what extent does adolescent motherhood interfere with schooling? We seek to shed light on these questions in the following sections.

\section{Empirical Strategy, Data and Variables}

Young women of high school age (15 to 19 years) make fertility and schooling decisions that affect their level of utility. We are interested in the determinants of the motherhood decisions by young Chilean women, and its subsequent effect on their secondary schooling outcomes.

We define latent variable $h_{i}^{*}$ that represents the utility from high school enrollment and completion obtained by youth $i$. The schooling outcome is a function of individual and family characteristics $\left(X_{i}\right)$, environmental variables such as school availability $\left(Y_{i}\right)$, and the amount of time dedicated to school-related activities. To the extent that motherhood requires time (for child care) that detracts from academic activities, being a mother $\left(M_{i}\right)$ is also a determinant of secondary schooling. We express its utility as:

$$
h_{i}^{*}=\alpha X_{i}+\beta Y_{i}+\delta M_{i}+\varepsilon_{i}
$$

where $X_{i}$ and $Y_{i}$ are as defined above, $M_{i}$ is a dummy variable which equals one if the teenager is a mother, and unobservable factors are captured by the error term of the schooling decision, $\varepsilon_{i}$.

Although utility is not observed, we have information on teenagers' choices regarding this decision. Let $h_{i}$ represent the observed high school enrollment/completion choices made by adolescent girls:

$$
h_{i}=\left\{\begin{array}{l}
1 \text { if the adolescent is enrolled in or completed high school } \\
0 \text { if the adolescent is not enrolled or dropped out of high school }
\end{array}\right.
$$

Depending on the level of utility that this activity reports, the youth decides whether to attend high school or not. Thus, the probability that youth $i$ attends school is given by: 


$$
\begin{aligned}
& h_{i}=1 \text { if } \operatorname{Pr}\left(h_{i}^{*}>0\right) \\
& h_{i}=1 \text { if } \operatorname{Pr}\left(\alpha X_{i}+\beta Y_{i}+\delta M_{i}+\varepsilon_{i h}>0\right)
\end{aligned}
$$

Our variable of interest—-the effect teenage motherhood on schooling —is captured by $\delta$.

\section{Empirical Specification}

In our empirical specification we assume that the probability distribution of $\varepsilon_{i}$ is linear and estimate the following linear regression:

$$
H_{i}=\alpha X_{i}+\beta Y_{i}+\delta M_{i}+\varepsilon_{i}
$$

where $H_{i}=1$ if the girl currently attends or has completed high school, and 0 if she does not currently attend or did not complete a secondary education.

Being a mother $\left(M_{i}\right)$ is potentially endogenous. The large literature on the effects of adolescent motherhood on schooling has indicated that teenage mothers are different from girls that do not have children in terms of observables (socio-economic backgrounds and community characteristics) and it also suggests that they may be different in terms of unobservable characteristics. Thus, estimating equation (2) linearly may give rise to an omitted variable bias so that $\delta$ is an inconsistent estimate of the true effect of motherhood on high school attendance/completion.

For example, fertility and high school decisions may be determined by a girl's ability for school: girls with lower academic skills are likely to find school more challenging than girls with higher ability, and they are more likely to drop out (Levine and Painter, 2003). Similarly, girls who have a difficult time in school face lower costs of becoming mothers during their teenage years. Thus, the variable $M_{i}$ is correlated with error term $\varepsilon_{i}$ and in this sense estimating equation (2) without correcting for the endogeneity produces a biased estimate of $\delta$, since part of the measured effect is due to differences in unobserved academic ability. 
To address the potential endogeneity problem and properly identify the effect of motherhood on school attainment, we apply the instrumental variables approach. The instrument (which we denote as $Z_{i}$ ) must be correlated with teenage motherhood, $M_{i}$, but uncorrelated with the error term of the school attainment decision, $\varepsilon_{i}$.

The literature on teenage fertility provides guidance as to which variables affect their motherhood decision (Snow et al, 1999). The list of potential instruments may be grouped in two categories: variables that capture social stigma regarding adolescent births (including family preferences), i.e., how acceptable is teenage pregnancy or unwed births in the young woman's social environment; and second, variables that measure availability of birth-control or sex education. To the extent that these are not correlated with high school attainment, variables that capture these factors would be appropriate instruments.

The empirical specification of the instrumental variable (IV) estimation is:

First stage: $\quad M_{i}=\phi X_{i}+\lambda Y_{i}+\pi Z_{i}+\rho_{i M}$

Second stage: $\quad H_{i}=\alpha^{*} X_{i}+\beta^{*} Y_{i}+\delta^{*} \hat{M}_{i}+\varepsilon_{i h}$

If the instrumental variable $Z_{i}$ is correlated with motherhood $(\pi \neq 0)$ and not with the schooling decision (i.e., $\operatorname{Cov}\left(Z_{i}, \varepsilon_{i h}\right)=0$ ) then it is an appropriate instrument and parameters $\alpha^{*}, \beta^{*}$ and $\delta^{*}$ are consistent estimates of the effects of the independent variables (including motherhood) on high school attendance/completion.

The first part of our discussion on the determinants of teenage motherhood in Chile will analyze results of the first stage of (3), and the second part of the discussion—on the effects of motherhood on secondary schooling—will discuss the second stage of the I.V. estimation.

\section{Data and Variables}

The individual and family background variables were obtained from eight repeated rounds 
of Chile's CASEN household surveys, ${ }^{7}$ which contain individual and family information about education, health, employment and income as well as the household's demographic composition. We limited the sample to teenage girls who are of childbearing and high-school age (15 to 19 years. $)^{8}$

\section{Dependent Variables}

The dependent variables — motherhood and high school attendance/completion-were constructed from the family composition and education sections of the CASEN survey, respectively. The CASEN survey is designed to measure socio-economic status and access to various social programs in Chile, so it does not contain a woman's complete fertility history. We construct the motherhood variable from the survey's household composition section. Multifamily households are common in Chile, ${ }^{9}$ so that individuals are asked their relationship to the head of the household and to the head of their family (nucleus). We define adolescent mothers as women aged 15 to 19 years who either: (i) are the head of their household (HH) or spouse of the $\mathrm{HH}$ and sons or daughters are present, or (ii) are the head of their family (within a larger household) and sons/daughters are present in their family unit. ${ }^{10}$

The education section of the survey asks whether individuals currently attend school and the highest level of education completed. We are interested in the effect of motherhood on secondary schooling — both attendance and completion. An adolescent is defined as "in school” if she currently attends or has already completed high school.

\footnotetext{
${ }^{7}$ CASEN is the abbreviation for National Socioeconomic Characterization surveys (Caracterización Socioeconómica Nacional). This paper uses all CASENs available, namely, surveys fielded in 1990, 1992, 1994, 1996, 1998, 2000, 2003 and 2006. The eight rounds are not a panel, however, panel CASEN data spanning the 19962006 period was recently made available and will be explored in a future version of this paper.

${ }^{8}$ The appropriate high school age in Chile is $14-18$ years. We exclude 14 year olds because the incidence of motherhood in the age distribution jumps from $0.5 \%$ to $1.9 \%$ between ages 14 and 15, respectively. We include 19 year-olds to keep grade repeaters in the sample, and because they are considered adolescents. As a robustness check, we conducted estimates including girls aged 14 years and excluding 19 year olds and the results did not change.

${ }^{9}$ In Chile, $17 \%$ of households had more than one family unit.

${ }^{10} 52 \%$ of adolescent mothers live with their parents, $14 \%$ live with their in-laws, and $24 \%$ live independently from parents or in-laws.
} 


\section{Explanatory Variables}

Individual characteristics include age and years of education completed by the adolescent, while family variables included information about age structure (number of elderly, number of children aged 6 to 14, and number of adults in the household), sex and education attainment of the head of the household, and total adult household income. We also controlled for household density (defined as the number of persons in the household per number of bedrooms) as a proxy for household wealth. ${ }^{11}$ Furthermore, studies have found that household density and sexually promiscuous behaviors are correlated and prevalent in Chile’s public housing.

Variables that capture environmental characteristics included a dummy for rural location and a variable that measures the proportion of high schools in the municipality that have full-day programs (henceforth JEC). ${ }^{12}$ We controlled for municipal-level characteristics that may affect the likelihood of the outcomes of interest, such as: average educational attainment, unemployment rate, and income per capita in the municipality. ${ }^{13}$ Additionally, to control for changes in economic conditions as well as for long-term trends in school enrollment and motherhood, we included a set of region-year effects in all estimations.

\section{Instruments}

The instrument to be included in first stage of the I.V. estimation must affect the motherhood outcome, but must not be correlated with the error term of the schooling decision. One possible set of instruments would measure the availability or access by teenagers to family planning, i.e., sex education and birth control. Despite the fact that numerous programs exist in Chile, they are disperse and no systematic data set has been compiled at a disaggregated level.

\footnotetext{
${ }^{11}$ Furthermore, studies have found that household density and sexually promiscuous behaviors are correlated and prevalent in Chile's public housing (ECLAC 2005).

12 In 1997, the Chilean government implemented an educational reform where one of the components-the Full School Day or Jornada Escolar Completa, (JEC)—-was the duration of the school day; in high schools it was lengthened from between 32-38 to 42 hours per week (1 to 2 additional hours per day.)

${ }^{13}$ Municipal-level variables are available through the Ministry of Planning.
} 
Nonetheless, we were able to construct several variables that capture social acceptance or stigma regarding teenage or unwed births.

The Ministry of Health's national birth registries provide information on all births between 1990 and 2004, which include a limited set of mothers'. Using Chile’s national birth registry and population estimates from its census bureau, we constructed the following municipal-level variables measuring the proportion of teenagers in the county who gave birth (henceforth the teenage pregnancy rate), and the average county rate of unwed births, for all years available. These variables are likely determinants of teenage fertility decisions yet we have no $a$ priori reason to expect them to be correlated with education decisions.

A potential omitted variable in equation (3) is family tastes regarding motherhood at young ages. If a family has a preference for or against young motherhood, it could affect the likelihood that a teenage girl becomes pregnant but not necessarily their school attainment. Thus, a third instrument is a dummy variable that equals 1 if the adolescent's mother was also a teenage mom (i.e. her age at first birth was less than 20), which we construct from the estimated difference between age of the teen's mother and her eldest child. The use of this instrument has two data limitations: (i) we limit our analysis to teenage girls who continue to live with their mothers; and (ii) we do not capture the full incidence of whether teenage girls' mothers were teens at first birth, because their age at first birth may be over-estimated if the oldest child no longer lives in the same household. ${ }^{14}$

Table 3 contains summary statistics of all variables included in the regressions. Panel (1) contains summary statistics for all adolescent girls in the CASEN surveys, while panel (2) contains statistics for the sample of girls that continue to live with their mothers, which is the

\footnotetext{
${ }^{14}$ The CASEN survey obtains information on all the residents of a household, so that sons or daughters that live elsewhere are not included. For example, a woman aged 36 years old may live in a household where the oldest son or daughter is aged 15 years, and her estimated age at first birth would be 21 and she is not reported as having been a teenage mom. If she has a child aged 20 who does not live in the home, her real age at first birth is 16.
} 
sample we include in all our estimations. As may be observed, our sample has "better" outcomes than the adolescent population at large: a higher proportion attends or finished high school, and a lower proportion of teens are adolescent mothers. In terms of observable characteristics, the variables are not statistically different in both samples. ${ }^{15}$

\section{[TABLE 3 HERE]}

Due to the data limitations discussed above, any estimated effects of teenage motherhood on schooling are lower-bounds in the following sense: we measure the impact of teen motherhood on a sub-sample of teens that has the support of their parents-both affective and economic — so that any negative effects from motherhood are ameliorated. If we were to estimate the effects on the larger sample with a higher incidence of teenage motherhood, it would likely be a stronger (negative) effect. ${ }^{16}$

We are interested in analyzing whether results differed across income groups. Thus, we performed our estimations by dividing the sample into higher and lower education families, based on the education level of the head of the household. Educational attainment is a proxy for a family's lifetime income, whereas the income measure from the surveys may be plagued by transitory income shocks. Thus, we defined a high-education (income) family as one where the head of the household completed a high school education or more, whereas a low-education (income) household is one with less than a high-school education.

\section{Empirical Results}

\footnotetext{
${ }^{15}$ We estimated t-tests on the difference of all variables; they were statistically the same at the $5 \%$ level.

${ }^{16}$ Indeed, estimation results in Table 5 reveal that the effect of adolescent motherhood is stronger in the full sample of teens (Column 1) than in the sample of teens that live with their mothers (Columns $2-4$ ).
} 
Our empirical results are presented in Tables 4 through 6. In Tables 4 and 5, the last two columns present results by whether the teenager lives in a high or low education (income) family. Where relevant, differences across family income groups will be discussed.

\section{Determinants of Adolescent Motherhood}

Table 4 presents our OLS results on the variables that determine the likelihood that a teenager is a mother (the first-stage regressions of our instrumental variables approach outlined in equations (3), above). ${ }^{17}$

\section{[TABLE 4 HERE]}

Column (1) presents the baseline estimations where the explanatory variables include only family characteristics (and a dummy variable for rural location). We find that if the adolescent's mother was a teenage mom herself, the probability that a girl is a mother is 0.007 greater than girls whose mother was not an adolescent mom. In relative terms this means that daughters of teenage mothers are 10 percent more likely to bear children in their adolescent years. ${ }^{18}$ This is evidence that family preferences for early childbearing are important in determining teenager's fertility outcomes, and suggests that policies oriented at preventing teen births may have externality or inter-temporal effects into future generations.

It is possible that part of the effect captured by whether a teenager's mother was also a teen mom may be due to the fact that adolescent mothers and their families are poor and they tend to live in disadvantaged neighborhoods with fewer economic opportunities (Kearney and Levine, 2007), so that the opportunity costs of childbirth are lower in such areas. To control for this possibility, column (2) controls for municipality characteristics such as: the share of full-time (JEC) high schools in the municipality, and the average education, unemployment rate and

\footnotetext{
${ }^{17}$ As a robustness check, we also estimated Probit regressions; the results did not change.

${ }^{18}$ The marginal effect is estimated as: (coefficient $\div$ mean of dependent variable) $\mathrm{x} 100$. In this case, the marginal effect $=(0.007 \div 0.068) \times 100=10 \%$. All results henceforth will be expressed as marginal effects.
} 
income per capita in the municipality. Column (3) also controls for municipality fixed effects to account for time-invariant municipal characteristics. Community characteristics play a role, yet they do not seem to affect the magnitudes (or statistical significance) of the effects of family and individual-level variables. The discussion below will center on results of column (3) and where relevant, the differences found between higher-income (column 4) and lower-income (column 5) adolescents are emphasized.

Results in column 3 reveal that once municipal characteristics and fixed effects are controlled for, if an adolescent's mother was a teenage mom she is 9 percent more likely to be a mother. This effect, is only found among higher education (income) households and among those youths, adolescents whose mothers were teenage mothers are 39 percent more likely to become mothers themselves.

Older girls are more likely to be mothers, and every year is critical: with each year that passes the probability that a girl becomes pregnant increases 70 percent. Education is important in the prevention of teenage childbearing, as each year of education reduces the likelihood that a girl is a mother by 35 percent.

Family structure is an important determinant of teenage childbearing. We find that the presence of an elderly person (aged 65 years or more) in the household, most likely a grand parent, reduces the likelihood of adolescent motherhood by 27 percent. This is probably because teenagers who live with a grandparent are under stricter adult supervision in the after-school hours than those who do not live with a grandparent. Furthermore, the effect is twice as large among higher-income vis-à-vis lower-income teens: the presence of an elderly family member is associated with a 42\% lower probability of motherhood among higher education homes compared to $24 \%$ among low-income families.

We also find that the presence of younger siblings (aged 6 to 14) reduces the likelihood of 
teen motherhood, and although the effect is smaller in magnitude than the one for grandparents (12 percent), it suggests that adolescent girls with siblings have greater responsibilities in taking care of younger brothers or sisters that detract them from riskier sexual behavior. The effect of young siblings on teen motherhood is statistically significant among lower-income families, which supports our hypothesis that greater responsibilities in domestic tasks are the explanation for this result, since higher-income households in Chile usually hire domestic workers to perform child-care and other domestic tasks. In sum, the two results regarding family structure suggest that family networks are important determinants of teenager's fertility outcomes.

Adolescents who live in female-headed households are 32 percent more likely to be teenage moms than those living in homes where the head of the household is a man. This result indicates that the design of public policies should account for the vulnerability faced by teenage girls in single-mother families. ${ }^{19}$

Once family structure and household demographics are controlled for, the effects of parental income are small: education of the head of the household does not significantly affect the likelihood of adolescent motherhood, and while adult income per capita significantly reduces its likelihood its effect is small (5 percent). Household wealth—as proxied by household density— on the other hand, has important effects: each additional household member present per bedrooms in the home is correlated with a 37 percent increase in the probability that an adolescent girl is a mother.

Environmental variables that measure economic conditions do not significantly affect the likelihood of teenage motherhood. Although the incidence of young motherhood is slightly higher in rural areas, ${ }^{20}$ once family income and education are controlled for we find that rural location is correlated with lower probabilities of adolescent motherhood relative to urban areas,

\footnotetext{
${ }^{19}$ Our estimations control for whether the head of the household is female, which is almost equivalent to singlemother households: 83 percent of female heads of households are single.

${ }^{20} 12.7$ percent of adolescent girls were mothers in rural areas compared to 10.4 percent in urban locations.
} 
probably because rural areas are less densely populated (reducing the likelihood of a teen pregnancy).

Girls with access to high schools that had ascribed to the full-time, JEC program were less likely to be mothers, and the effect exists among lower-income adolescents. This may be due to two possible effects described in Blank et al. (2004): the incarceration effect, whereby teens spend more hours in school and have less time to engage in risky activities, and the human capital effect, where higher education increases an adolescent's human capital and thus affects her fertility decisions. Although the JEC program was designed to improve the quality of education of Chile's public schools, the program's description recognizes that among socially vulnerable children, schools are not only centers of learning but also spaces that protect the child from risks such as school desertion, drugs, and child labor. ${ }^{21}$ Our findings reveal that the program has been successful in reaching its objective to reduce risky behavior among teens from lower-income families, since those that have more access to JEC schools are less likely to become young mothers.

\section{Effects of Adolescent Motherhood}

The effects of adolescent motherhood on high school enrollment or completion are presented in Tables 5 and 6: Table 5 contains results from the linear (OLS) estimations, whereas Table 6 contains results from the instrumental variables (I.V.) estimates.

\section{Linear estimations - OLS}

Columns 1 and 2 of Table 5 present results of the effect of motherhood on schooling, controlling only for individual and family characteristics. Column 1 contains the entire sample of adolescents regardless of their living arrangements, while column 2 contains the sample used in the remainder of the estimations, i.e., adolescent girls that live with their mothers. As discussed

\footnotetext{
${ }^{21}$ Description of the JEC program may be found (in Spanish) at: http://www.mineduc.cl/index0.php?id_portal=21
} 
above, the larger sample in column 1 includes teens that have formed their own households independently from their parents, who have worse schooling and fertility outcomes, i.e., less schooling and higher motherhood rates. When these teens are included in the sample (column 1) the negative effect of motherhood on schooling is greater $(-0.34)$ than when they are excluded in column $2(-0.31)$. In order to be able to use the age of the teenager's mother as an instrument in I.V. regressions, all estimations are performed on the limited sample of adolescent girls who still live with their parents. As discussed above, the effects found are likely to be lower-bound effects of motherhood on schooling.

\section{[TABLE 5 HERE]}

Columns 3 and 4 control for time varying municipal characteristics and fixed effects, respectively. All Henceforth we discuss results of column (4), highlighting differences across family education (income) groups where relevant.

Adolescents who are mothers are 37 percent less likely to be enrolled in or have completed high school than those who are not mothers. ${ }^{22}$ Furthermore, the effect is twice as strong among vulnerable, lower-income youths who are 41 percent less likely to continue their high school education if they become mothers, compared to higher-income girls who are 22 percent more likely to abandon high school with a birth. These findings reveal that motherhood and schooling are not complementary activities and that economically disadvantaged youths would benefit from policies that encourage high-school completion, such as targeted child care subsidies or child care facilities on school grounds.

Other explanatory variables display the expected signs. As adolescent girls get older, they are less likely to attend high school; each year that passes is correlated with an 11 percent lower probability of continuing in or completing a secondary education. On the other hand, each

\footnotetext{
${ }^{22}$ The marginal effect is estimated as: (coefficient $\div$ mean of dependent variable) $\mathrm{x} 100$. In this case, the marginal effect $=(-0.3108 \div 0.8311) \times 100=37 \%$.
} 
additional year of educational attainment, i.e., each year that girls remain in high school is correlated with a 12 percent higher likelihood that they will continue/complete their studies.

The family's demographic composition also affects the likelihood of secondary school attendance and completion. We find that the presence of elderly family members in the household is correlated with a higher likelihood of schooling, and that the presence of younger siblings is correlated with lower schooling of teenage girls in lower-income families only, which is additional evidence that adolescent girls in poorer households have domestic responsibilities that higher-income girls do not.

Girls that live in female-headed households are less likely to continue in school than those that live in male-headed households, even when controlling for income levels. This result is probably due to the fact that in female-headed (mostly single mother) homes, mothers rely on their teenage daughters to take care of domestic tasks or to supply the household with additional income, which conflict with school-related activities. Education of the head of the household, as well as total adult income, are positively correlated with the likelihood that young lower-income girls remain in high school, which reveal that conditional income transfers or targeted scholarships are effective policies to increase school attainment in Chile. Household wealth (proxied by household density) is positively correlated with schooling: girls that live in homes with lower housing density are more likely to continue their secondary education.

With regards to environmental variables, we find that adolescent girls in lower-income groups who reside in rural areas are less likely to attend or complete high school than urban residents, but the marginal effect is small in magnitude (7\%). Surprisingly, the share of high schools in the municipality that offer full-time JEC programs does not affect the probability that girls attend high school. 
Instrumental Variable Results - I.V.

The methodological challenge of estimating the effect of motherhood on schooling (and other human capital) outcomes is identification, disentangling the causality of being a mother from an adolescent's unobserved characteristics that may be driving both the motherhood and schooling decisions. In this sense, the OLS coefficient over-estimates the true effect of teen motherhood. Instrumental variables would address this problem and reduce the over-estimation, to the extent that the instrument is correlated with the probability of motherhood but not with schooling.

\section{[TABLE 6 HERE]}

We use three available variables as instruments in our estimation: (i) whether the adolescent's mother was a teenage mom herself, to capture family preferences regarding young childbearing, (ii) the municipal teenage birth rate, and (iii) municipal unwed birth rates to capture changing social acceptance of teenage births. Table 6 presents all I.V. results, as well as the OLS results in column 1 as a baseline and to motivate the comparison of I.V. and O.L.S. estimations. ${ }^{23}$ Columns $2-5$ present results of different specifications of the I.V. estimations that used one, two or three instrumental variables. ${ }^{24}$ Table 6 reports which instruments are included in each specification and whether they are statistically significant (at the 5 and 1 percent level of significance) in the first stage of the estimation. Our instruments - whether the teen's mother was an adolescent mother, and municipal-level teenage birth and unwed birth rates-were uncorrelated with the schooling outcome and were jointly significant determinants of teen

\footnotetext{
${ }^{23}$ Column 1 of Table 6 corresponds to column 4 of Table 5. All I.V. specifications included municipality fixed effects to control for time-invariant geographic characteristics and region-year effects to control for time and regional trends in the variables of interest.

${ }^{24}$ We tested for whether the instruments were exogenous with the Durbin-Wu-Hausman test of exogeneity with a null hypothesis that all OLS coefficients are the same as IV estimates; in all cases, we cannot reject the null hypothesis.
} 
motherhood in three of the four specifications found in Table $6 .^{25}$

The empirical specification in column 2 corresponds to including whether the teenager's mother was an adolescent mom-henceforth TeenMom² —in the I.V. regressions. Columns 3 and 4 contain results from including TeenMom ${ }^{2}$ and the municipal teenage birth rate (col. 3) and unwed birth rate (col. 4), respectively; column 5 includes all three instrumental variables in the estimation. Wherever more than one instrument was used we performed a test of over-identifying restrictions and find that there is no over-identification.

I.V. estimations reveal that the magnitude of the effect of teen motherhood is smaller than OLS estimates, ranging from a reduction in high school attendance of 21 - 31 percent (compared to a 37 percent reduction with the linear estimation). Thus, instrumental variables estimation reduces the endogeneity bias and finds that the true effect of adolescent motherhood on schooling is not only different from zero but that it is of important economic significance. Programs and policies aimed at preventing teen pregnancies would generate a significant impact in reducing high school desertion in Chile, especially among more disadvantaged youths.

\section{Concluding Comments}

This paper analyzed the determinants of teenage motherhood in Chile, and its effects on high school enrollment and completion. We found that adolescents from higher income households whose mothers were teenage mothers are 39 percent more likely to become mothers themselves, which reveals that family preferences regarding young childbearing are passed on across generations. We find that older girls with lower school attainment are more likely to become mothers, regardless of their income level.

\footnotetext{
${ }^{25}$ F-tests of the instrumental variables in the first stage of the I.V. estimation find that they are significant at the $5 \%$ level (column 2), and jointly significant at the 10\% level (columns 3 and 4). As part of the verification process, we included the instruments in the second stage regressions and in all cases they were statistically insignificant, validating them as potential instruments since they are uncorrelated with high school attendance outcomes.
} 
Family networks are also important determinants of adolescent fertility: the presence of grandparents in the household reduces the likelihood that teenage girls become mothers, reflecting increased adult supervision in those homes that deter risky sexual behavior. The presence of younger, school-aged siblings is correlated with a lower probability of adolescent motherhood but only among lower-income teens, which suggests that young women in Chile are responsible for child-care duties that require time, which is also a deterrent of risky sexual activities. The effect of sibling presence is not present among higher income adolescents who probably count on hired domestic help in the domestic duties (including child care) of the household.

Meanwhile, teenagers that live in female-headed households—-which is almost equivalent to single mother families - are more likely to become mothers, regardless of their income status. Income and wealth had the expected effect on adolescent childbearing: higher adult incomes and higher wealth (proxied by lower household density) result in lower probabilities of teen motherhood.

One of our most interesting findings reveals that school availability reduces the probability of teen motherhood, especially among socially disadvantaged youths: low-income girls that live in municipalities with higher fractions of full-day high school programs (JEC) were less likely to become mothers.

The second part of our estimations measured the effect of adolescent motherhood on high school attendance and completion. Our linear estimations reveal that girls who are mothers are 37 percent less likely to attend or have completed high school. We account for the possibility of endogeneity due to unobservable characteristics and measure the effect of teen motherhood with instrumental variables estimations. Our instruments are appropriate in the sense that they are uncorrelated with the schooling outcome and significant determinants of teen motherhood. Once 
we accounted for the possible endogeneity (due to unobservable characteristics), we find that adolescents who are mothers are between 21 and 31 percent less likely to attend or have completed high school than girls who were not mothers. The I.V. estimations reveal that indeed OLS measures over-estimate the effect of teen motherhood, but that it is significantly different from zero—both statistically and economically.

We also find that older girls with lower school attainments are more likely to drop out of high school, and that family composition affects secondary schooling: girls living with grandparents are more likely to attend school, whereas lower-income girls with younger schoolaged siblings are less likely to attend than those that do not have younger siblings, reflecting the burden of domestic responsibilities that lower income girls bear in Chile. Girls living in femaleheaded households are less likely to attend high school, and income and wealth measure have the expected signs. 


\section{References}

Ashcraft, A., Lang, K. 2006. The Consequences of Teenage Childbearing. National Bureau of Economic Research, Working Paper No. 12485.

Black, S.E., Devereux, P.J., Salvanes, K.G. 2008. Staying in the classroom and out of the maternity ward? The effect of compulsory schooling laws on teenage births. The Economic Journal, 118, 1025-1054.

Buvinic, M. 1998. The Costs of Adolescent Childbearing: Evidence from Chile, Barbados, Guatemala and Mexico. Studies in Family Planning, 29(2), pp. 201-209.

ECLAC (Economic Commission for Latin America and the Caribbean). 2005. Políticas sociales de vivienda, pobreza y ciudadanía en Chile: Un estudio de caso desde la etnografía. Mimeo, Proyecto Regional de Población CELADE-UNFPA.

Fletcher, J.M., Wolfe, B.L. 2008. Education and Labor Market Consequences of Teenage Childbearing: Evidence Using the Timing of Pregnancy Outcomes and Community Fixed Effects. National Bureau of Economic Research, Working Paper No.13847.

Geronimus, A.T., Korenman, S. 1992. The Socioeconomic Consequences of Teen Childbearing Reconsidered. Quarterly Journal of Economics. 107(4), pp.1187-1214.

Geronimus, A.T., Korenman, S. 1993. The Socioeconomic Consequences of Teen Childbearing: Evidence and Interpretation. Demography. 30(2), pp.281-290.

Gorgger, J., Bronars, S.G. 1993. The socioeconomic consequences of teenage childbearing: findings from a natural experiment. Family Planning Perspectives, 25(4), pp.156-161,174.

Hoffman, S.D. 1998. Teenage Childbearing is not So Bad After All... Or Is It? A Review of the New Literature. Family Planning Perspectives, 30(5), pp.236-239,243.

Hoffman, S.D., Foster, E.M., Furstenberg, F.F. 1993. Reevaluating the Costs of Teenage Childbearing. Demography. 30(1), pp.1-13.

Hotz, V. J., McElroy, S.W., Sanders, S.G. (1999). Teenage Childbearing and Its Life Cycle Consequences: Exploiting a Natural Experiment. Journal of Human Resources, 40(3), pp.683-715. Jones, A.S., Astone, N.M., Keyl, P.m., Kim, Y.J., Alexander, C.S. 1999. Teen Childbearing and Educational Attainment: A Comparison of Methods. Journal of Family and Economic Issues, Vol. 20(4), pp.387-418.

Kearney, M.S., Levine, P.B. 2007. Socioeconomic Disadvantage and Early Childbearing. National Bureau of Economic Research, Working Paper 13436. 
Levine, D.I., Painter, G. 2003. The Schooling Costs of Teenage Out-of-Wedlock Childbearing: Analysis with a Within-School Propensity-Score-Matching Estimator. Review of Economics and Statistics, 85(4), pp.884-900.

MIDEPLAN (Ministerio de Planificación). 2003. Adolescentes y jóvenes que abandonan sus estudios antes de finalizar la enseñanza media: Principales tendencias. Mimeo. http://www.mideplan.cl/casen/pdf/desercionescolar.pdf

Singh, S. 1998. Adolescent childbearing in developing countries: a global review. Studies in Family Planning, 29(2), pp.117-36.

The World Bank. 2006. Chile Development Policy Review, Volume II. Report No. 33501-CL. Washington, D.C. 
Table 1. Rates of high school attendance/completion and adolescent motherhood, 1990 - 2006 (\%)

\begin{tabular}{c|cc|cc}
\hline \multirow{2}{*}{ Year } & \multicolumn{2}{|c|}{$\begin{array}{c}\text { Currently attends or has } \\
\text { completed high school (\%) }\end{array}$} & \multicolumn{2}{c}{ Adolescent mother (\%) } \\
\cline { 2 - 5 } & Yes & No & Yes & No \\
\hline 1990 & 74.8 & 25.2 & 9.9 & 90.1 \\
1992 & 71.0 & 29.0 & 9.8 & 90.2 \\
1994 & 70.7 & 29.3 & 10.7 & 89.3 \\
1996 & 76.4 & 23.6 & 10.4 & 89.6 \\
1998 & 77.6 & 22.4 & 11.5 & 88.5 \\
2000 & 78.9 & 21.1 & 13.8 & 86.2 \\
2003 & 84.1 & 15.9 & 12.3 & 87.7 \\
2006 & 86.7 & 13.3 & 9.5 & 90.5 \\
\hline \multirow{2}{*}{ Average } & $\mathbf{7 9 . 2}$ & $\mathbf{2 0 . 8}$ & $\mathbf{1 1 . 2}$ & $\mathbf{8 8 . 8}$ \\
\hline
\end{tabular}

Source: Authors' calculations based on CASEN surveys, 1990-2006. Proportion of adolescent girls aged 15 to 19 who attend / completed high school and who were mothers. 


\begin{tabular}{ccccc}
\hline $\begin{array}{c}\text { Table 2. Chilean births, 1990 - 2004: } \\
\text { mothers' age (\%) }\end{array}$ & Distribution of \\
\hline \multicolumn{5}{c}{ Age of Mothers: } \\
Year & $\mathbf{1 4 - 1 9}$ & $\mathbf{2 0 - 2 9}$ & $\mathbf{3 0 - 3 9}$ & $\mathbf{4 0 - 4 9}$ \\
\hline 1990 & 13.7 & 58.1 & 26.2 & 2.0 \\
1991 & 13.7 & 56.7 & 27.4 & 2.1 \\
1992 & 13.7 & 55.6 & 28.4 & 2.2 \\
1993 & 13.9 & 54.7 & 29.1 & 2.3 \\
1994 & 14.1 & 54.1 & 29.5 & 2.3 \\
1995 & 14.5 & 52.9 & 30.0 & 2.4 \\
1996 & 14.9 & 51.9 & 30.6 & 2.5 \\
1997 & 15.6 & 50.9 & 30.9 & 2.6 \\
1998 & 16.1 & 50.0 & 31.1 & 2.7 \\
1999 & 16.1 & 49.2 & 31.8 & 2.8 \\
2000 & 16.1 & 48.6 & 32.2 & 3.0 \\
2001 & 16.1 & 47.8 & 32.8 & 3.2 \\
2002 & 15.7 & 47.8 & 33.1 & 3.4 \\
2003 & 14.8 & 47.3 & 34.2 & 3.6 \\
2004 & 14.9 & 46.7 & 34.6 & 3.7 \\
\hline Average & $\mathbf{1 4 . 9}$ & $\mathbf{5 1 . 7}$ & $\mathbf{3 0 . 6}$ & $\mathbf{2 . 7}$ \\
\hline Authors' estimates based on the Ministry of Health's National Registry of \\
Births, 1990-2006. Proportion of mothers in the corresponding age \\
groups (\%).
\end{tabular}


Table 3. Summary Statistics

\begin{tabular}{|c|c|c|c|c|c|c|c|c|c|c|c|c|}
\hline \multirow[t]{2}{*}{ Variable } & \multicolumn{2}{|c|}{$\begin{array}{c}\text { (1) } \\
\text { All Adolescents }\end{array}$} & \multicolumn{2}{|c|}{$\begin{array}{c}(2) \\
\text { Sample }\end{array}$} & \multicolumn{2}{|c|}{$\begin{array}{c}(3) \\
\text { Not mothers }\end{array}$} & \multicolumn{2}{|c|}{$\begin{array}{c}\text { (4) } \\
\text { Mothers }\end{array}$} & \multicolumn{2}{|c|}{$\begin{array}{c}\text { (5) } \\
\text { H.S. }+ \\
\end{array}$} & \multicolumn{2}{|c|}{$\begin{aligned} & (6) \\
< & \text { H.S. }\end{aligned}$} \\
\hline & mean & s.d. & mean & s.d. & mean & s.d. & mean & s.d. & mean & s.d. & mean & s.d. \\
\hline Attends/finished H.S. & 0.792 & 0.406 & 0.840 & 0.366 & 0.873 & 0.333 & 0.385 & 0.487 & 0.968 & 0.177 & 0.795 & 0.404 \\
\hline Adolescent mother & 0.112 & 0.315 & 0.068 & 0.252 & & & & & 0.038 & 0.190 & 0.079 & 0.269 \\
\hline Mother was teenage mom & 0.246 & 0.431 & 0.245 & 0.430 & 0.241 & 0.428 & 0.297 & 0.457 & 0.190 & 0.393 & 0.265 & 0.441 \\
\hline Age & 17.0 & 1.4 & 16.9 & 1.4 & 16.8 & 1.4 & 17.9 & 1.2 & 16.8 & 1.4 & 16.9 & 1.4 \\
\hline Num.children aged 6-14 & 0.79 & 0.93 & 0.85 & 0.93 & 0.85 & 0.93 & 0.87 & 0.97 & 0.77 & 0.83 & 0.88 & 0.97 \\
\hline Female-headed hhold & 0.21 & 0.41 & 0.20 & 0.40 & 0.19 & 0.39 & 0.27 & 0.44 & 0.18 & 0.38 & 0.21 & 0.40 \\
\hline Educ.head of hhold (years) & 7.7 & 4.3 & 7.9 & 4.3 & 8.0 & 4.3 & 6.8 & 3.8 & 13.5 & 2.2 & 6.0 & 3.0 \\
\hline Income per capita (logs) & 10.4 & 2.1 & 10.5 & 1.9 & 10.5 & 1.9 & 10.1 & 2.1 & 4.3 & 1.8 & 3.3 & 1.9 \\
\hline Income per capita (\$000) & 81.0 & 174.1 & 84.4 & 181.5 & 87.0 & 186.9 & 49.1 & 63.1 & 169.1 & 310.7 & 54.4 & 83.1 \\
\hline Municipality education (years) & 8.7 & 1.5 & 8.8 & 1.5 & 8.8 & 1.5 & 8.7 & 1.4 & 9.6 & 1.6 & 8.5 & 1.4 \\
\hline Municipality unempl. (\%) & 8.3 & 3.8 & 8.3 & 3.8 & 8.3 & 3.8 & 8.6 & 3.9 & 8.3 & 3.7 & 8.3 & 3.9 \\
\hline Municipality income (logs) & 6.0 & 0.4 & 6.0 & 0.4 & 6.0 & 0.4 & 5.9 & 0.4 & 6.2 & 0.5 & 5.9 & 0.4 \\
\hline Municipality income (\$000) & 432 & 315 & 437 & 327 & 439 & 335 & 409.145 & 203.2 & 579 & 520 & 387 & 199 \\
\hline Municipality rate of teen births & 0.063 & 0.020 & 0.063 & 0.020 & 0.063 & 0.020 & 0.066 & 0.022 & 0.058 & 0.021 & 0.065 & 0.020 \\
\hline No. of Observations & \multicolumn{2}{|c|}{64,197} & \multicolumn{2}{|c|}{52,327} & \multicolumn{2}{|c|}{48,770} & \multicolumn{2}{|c|}{3,557} & \multicolumn{2}{|c|}{13,704} & \multicolumn{2}{|c|}{38,623} \\
\hline
\end{tabular}

Authors' estimates from CASENs 1990-2006. (1) Includes adolescent girls aged 15-19 years. (2) Includes adolescent girls still living with their parents. (3) Includes adolescents who are not mothers; (4) includes adolescent mothers. (5) Includes adolescents whose head of household obtained a high school education or more; and (6) includes adolescents whose head of household obtained less than a high school education. 


\section{Table 4. Determinants of Adolescent Motherhood - OLS Estimations}

\begin{tabular}{|c|c|c|c|c|c|}
\hline $\begin{array}{l}\text { Dependent variable: Teen is a mother } \\
\text { Teen is a mother }\end{array}$ & $\begin{array}{c}\text { (1) } \\
\text { Baseline }\end{array}$ & $\begin{array}{c}\text { (2) } \\
\text { Comu Chars }\end{array}$ & $\begin{array}{c}\text { (3) } \\
\text { Comu FE }\end{array}$ & $\begin{array}{c}\text { (4) } \\
\text { High School + }\end{array}$ & $\begin{array}{c}(5) \\
\text { Less than H.S. }\end{array}$ \\
\hline Mother was an adolescent mom & $\begin{array}{l}0.0072 \\
(0.0027)^{* *}\end{array}$ & $\begin{array}{l}0.0072 \\
(0.0027)^{* *}\end{array}$ & $\begin{array}{l}0.0059 \\
(0.0028)^{*}\end{array}$ & $\begin{array}{l}0.0147 \\
(0.0050)^{* *}\end{array}$ & $\begin{array}{l}0.0034 \\
(0.0033)\end{array}$ \\
\hline Age & $\begin{array}{l}0.0475 \\
(0.0013)^{* *}\end{array}$ & $\begin{array}{l}0.0474 \\
(0.0013)^{* *}\end{array}$ & $\begin{array}{l}0.0475 \\
(0.0013)^{* *}\end{array}$ & $\begin{array}{l}0.0348 \\
(0.0026)^{* *}\end{array}$ & $\begin{array}{l}0.0511 \\
(0.0015)^{* *}\end{array}$ \\
\hline Schooling (years) & $\begin{array}{l}-0.0205 \\
(0.0009)^{* *}\end{array}$ & $\begin{array}{l}-0.0205 \\
(0.0009) * *\end{array}$ & $\begin{array}{l}-0.0204 \\
(0.0009) * *\end{array}$ & $\begin{array}{l}-0.0159 \\
(0.0021)^{* *}\end{array}$ & $\begin{array}{l}-0.021 \\
(0.0010)^{* *}\end{array}$ \\
\hline Num. Elderly (65yrs+) & $\begin{array}{l}-0.0187 \\
(0.0025)^{* *}\end{array}$ & $\begin{array}{l}-0.0188 \\
(0.0025)^{* *}\end{array}$ & $\begin{array}{l}-0.0185 \\
(0.0025)^{* *}\end{array}$ & $\begin{array}{l}-0.0106 \\
(0.0043)^{*}\end{array}$ & $\begin{array}{l}-0.0192 \\
(0.0028)^{* *}\end{array}$ \\
\hline Num.children aged 6-14 & $\begin{array}{l}-0.0086 \\
(0.0013)^{* *}\end{array}$ & $\begin{array}{l}-0.0086 \\
(0.0013)^{* *}\end{array}$ & $\begin{array}{l}-0.0083 \\
(0.0013)^{* *}\end{array}$ & $\begin{array}{l}-0.0042 \\
(0.0022)\end{array}$ & $\begin{array}{l}-0.0091 \\
(0.0016)^{* *}\end{array}$ \\
\hline Female-headed hhold & $\begin{array}{l}0.0221 \\
(0.0030)^{* *}\end{array}$ & $\begin{array}{l}0.022 \\
(0.0030)^{* *}\end{array}$ & $\begin{array}{l}0.0218 \\
(0.0030)^{* *}\end{array}$ & $\begin{array}{l}0.019 \\
(0.0048)^{* *}\end{array}$ & $\begin{array}{l}0.0239 \\
(0.0037)^{* *}\end{array}$ \\
\hline Education-head of hhold (years) & $\begin{array}{l}-0.0005 \\
(0.0003)\end{array}$ & $\begin{array}{l}-0.0006 \\
(0.0003)\end{array}$ & $\begin{array}{l}-0.0004 \\
(0.0003)\end{array}$ & $\begin{array}{l}0.0001 \\
(0.0006)\end{array}$ & $\begin{array}{l}0.0006 \\
(0.0005)\end{array}$ \\
\hline Hhold income/capita & $\begin{array}{l}-0.0036 \\
(0.0007)^{* *}\end{array}$ & $\begin{array}{l}-0.0037 \\
(0.0007)^{* *}\end{array}$ & $\begin{array}{l}-0.0036 \\
(0.0007)^{* *}\end{array}$ & $\begin{array}{l}-0.0024 \\
(0.0011)^{*}\end{array}$ & $\begin{array}{l}-0.0039 \\
(0.0009)^{* *}\end{array}$ \\
\hline Hhold density & $\begin{array}{l}0.0249 \\
(0.0015)^{* *}\end{array}$ & $\begin{array}{l}0.0249 \\
(0.0014)^{* *}\end{array}$ & $\begin{array}{l}0.0255 \\
(0.0014)^{* *}\end{array}$ & $\begin{array}{l}0.0321 \\
(0.0037)^{* *}\end{array}$ & $\begin{array}{l}0.0245 \\
(0.0016)^{* *}\end{array}$ \\
\hline Rural location & $\begin{array}{l}-0.0115 \\
(0.0030)^{* *}\end{array}$ & $\begin{array}{l}-0.0107 \\
(0.0031)^{* *}\end{array}$ & $\begin{array}{l}-0.0093 \\
(0.0031)^{* *}\end{array}$ & $\begin{array}{l}0.0038 \\
(0.0072)\end{array}$ & $\begin{array}{l}-0.0096 \\
(0.0034)^{* *}\end{array}$ \\
\hline Municipality \% of full-time high schools & & $\begin{array}{l}-0.0058 \\
(0.0052)\end{array}$ & $\begin{array}{l}-0.0133 \\
(0.0064)^{*}\end{array}$ & $\begin{array}{l}0.006 \\
0.0117)\end{array}$ & $\begin{array}{l}-0.0185 \\
(0.0071)^{* *}\end{array}$ \\
\hline Municipality mean education (years) & & $\begin{array}{l}-0.0002 \\
(0.0020)\end{array}$ & $\begin{array}{l}0.0004 \\
(0.0036)\end{array}$ & $\begin{array}{l}0.0034 \\
(0.0057)\end{array}$ & $\begin{array}{l}0.0005 \\
(0.0045)\end{array}$ \\
\hline Municipality unemployment rate (\%) & & $\begin{array}{l}0.0004 \\
(0.0004)\end{array}$ & $\begin{array}{l}-0.0006 \\
(0.0005)\end{array}$ & $\begin{array}{l}0.0014 \\
(0.0008)\end{array}$ & $\begin{array}{l}-0.0011 \\
(0.0006)\end{array}$ \\
\hline Municipality mean income & & $\begin{array}{l}0.0038 \\
(0.0062)\end{array}$ & $\begin{array}{l}0.0052 \\
(0.0087)\end{array}$ & $\begin{array}{l}0.0014 \\
(0.0121)\end{array}$ & $\begin{array}{l}0.0051 \\
(0.0109)\end{array}$ \\
\hline Constant & $\begin{array}{l}-0.5723 \\
(0.0189)^{* *}\end{array}$ & $\begin{array}{l}-0.5952 \\
(0.0328)^{* *}\end{array}$ & $\begin{array}{l}-0.6157 \\
(0.0526)^{* *}\end{array}$ & $\begin{array}{l}-0.4949 \\
(0.0727)^{* *}\end{array}$ & $\begin{array}{l}-0.6778 \\
(0.0633)^{* *}\end{array}$ \\
\hline Municipality characteristics & NO & YES & YES & YES & YES \\
\hline Municipality fixed effects & NO & NO & YES & YES & YES \\
\hline Observations & 52,327 & 52,327 & 52,327 & 13,704 & 38,623 \\
\hline R-squared & 0.09 & 0.09 & 0.10 & 0.10 & 0.10 \\
\hline Mean - Dependent Variable (observed) & 0.068 & 0.068 & 0.068 & 0.038 & 0.079 \\
\hline$\%$ Correctly predicted & 0.160 & 0.160 & 0.160 & 0.032 & 0.205 \\
\hline
\end{tabular}

Includes adolescent girls aged 15-19 years. * significant at 5\%; ** significant at 1\%. Robust standard errors in parentheses. Not shown: region-year and muncipality fixed effects. No. of clusters $=332$. Household density=number of persons/number of bedrooms in hhold. Municipality teenage pregnancy rate=\% of girls aged 15 to 19 that became mothers (in the municipality). 
Table 5. Adolescent motherhood effects on Schooling - OLS estimations

\begin{tabular}{|c|c|c|c|c|c|c|}
\hline $\begin{array}{l}\text { Dependent variable: Adolescent } \\
\text { attends or completed high school }\end{array}$ & \begin{tabular}{|c|}
$(1)$ \\
All Teens \\
\end{tabular} & $\begin{array}{c}(2) \\
\text { Baseline } \\
\end{array}$ & $\begin{array}{c}\text { (3) } \\
\text { MuniChars } \\
\end{array}$ & $\begin{array}{c}\text { (4) } \\
\text { MuniF.E. }\end{array}$ & $\begin{array}{c}(5) \\
\text { H.S. }+ \\
\end{array}$ & $\begin{array}{c}(6) \\
<\text { H.S. }\end{array}$ \\
\hline Adolescent is a mother & $\begin{array}{l}-0.3407 \\
(0.0058)^{* *}\end{array}$ & $\begin{array}{l}-0.3071 \\
(0.0074)^{* *}\end{array}$ & $\begin{array}{l}-0.3071 \\
(0.0074)^{* *}\end{array}$ & $\begin{array}{l}-0.3075 \\
(0.0074)^{* *}\end{array}$ & $\begin{array}{l}-0.2147 \\
(0.0187)^{* *}\end{array}$ & $\begin{array}{l}-0.3236 \\
(0.0082)^{* *}\end{array}$ \\
\hline Age & $\begin{array}{l}-0.0926 \\
(0.0012)^{* *}\end{array}$ & $\begin{array}{l}-0.0905 \\
(0.0014)^{* *}\end{array}$ & $\begin{array}{l}-0.0905 \\
(0.0014)^{* *}\end{array}$ & $\begin{array}{l}-0.0902 \\
(0.0014)^{* *}\end{array}$ & $\begin{array}{l}-0.0504 \\
(0.0029)^{* *}\end{array}$ & $\begin{array}{l}-0.0944 \\
(0.0015)^{* *}\end{array}$ \\
\hline Schooling (years) & $\begin{array}{l}0.1052 \\
(0.0012)^{* *}\end{array}$ & $\begin{array}{l}0.1029 \\
(0.0015)^{* *}\end{array}$ & $\begin{array}{l}0.1028 \\
(0.0015)^{* *}\end{array}$ & $\begin{array}{l}0.1025 \\
(0.0015)^{* *}\end{array}$ & $\begin{array}{l}0.0558 \\
(0.0031)^{* *}\end{array}$ & $\begin{array}{l}0.108 \\
(0.0015)^{* *}\end{array}$ \\
\hline Num. Elderly (65yrs+) & $\begin{array}{l}0.0127 \\
(0.0026)^{* *}\end{array}$ & $\begin{array}{l}0.0097 \\
(0.0029)^{* *}\end{array}$ & $\begin{array}{l}0.0096 \\
(0.0029)^{* *}\end{array}$ & $\begin{array}{l}0.0102 \\
(0.0029)^{* *}\end{array}$ & $\begin{array}{l}0.0028 \\
(0.0039)\end{array}$ & $\begin{array}{l}0.0124 \\
(0.0034)^{* *}\end{array}$ \\
\hline Num.children aged 6-14 & $\begin{array}{l}0.0016 \\
(0.0017)\end{array}$ & $\begin{array}{l}-0.0042 \\
(0.0018)^{*}\end{array}$ & $\begin{array}{l}-0.0041 \\
(0.0018)^{*}\end{array}$ & $\begin{array}{l}-0.0037 \\
(0.0018)^{*}\end{array}$ & $\begin{array}{l}0.0003 \\
(0.0020)\end{array}$ & $\begin{array}{l}-0.0042 \\
(0.0021)^{*}\end{array}$ \\
\hline Female-headed hhold & $\begin{array}{l}-0.0027 \\
(0.0030)\end{array}$ & $\begin{array}{l}-0.0101 \\
(0.0033)^{* *}\end{array}$ & $\begin{array}{l}-0.0102 \\
(0.0033)^{* *}\end{array}$ & $\begin{array}{l}-0.0103 \\
(0.0033)^{* *}\end{array}$ & $\begin{array}{l}-0.0088 \\
(0.0039)^{*}\end{array}$ & $\begin{array}{l}-0.0104 \\
(0.0041)^{*}\end{array}$ \\
\hline Education-head of hhold (years) & $\begin{array}{l}0.0042 \\
(0.0004)^{* *}\end{array}$ & $\begin{array}{l}0.005 \\
(0.0004)^{* *}\end{array}$ & $\begin{array}{l}0.0049 \\
(0.0004)^{* *}\end{array}$ & $\begin{array}{l}0.005 \\
(0.0004)^{* *}\end{array}$ & $\begin{array}{l}0.0004 \\
(0.0005)\end{array}$ & $\begin{array}{l}0.0062 \\
(0.0006)^{* *}\end{array}$ \\
\hline Hhold income/capita & $\begin{array}{l}0.0043 \\
(0.0008)^{* *}\end{array}$ & $\begin{array}{l}0.0026 \\
(0.0009)^{* *}\end{array}$ & $\begin{array}{l}0.0026 \\
(0.0009)^{* *}\end{array}$ & $\begin{array}{l}0.0029 \\
(0.0009)^{* *}\end{array}$ & $\begin{array}{l}0.0006 \\
(0.0009)\end{array}$ & $\begin{array}{l}0.0043 \\
(0.0011)^{* *}\end{array}$ \\
\hline Hhold density & $\begin{array}{l}-0.0123 \\
(0.0016)^{* *}\end{array}$ & $\begin{array}{l}-0.0137 \\
(0.0017)^{* *}\end{array}$ & $\begin{array}{l}-0.0137 \\
(0.0017)^{* *}\end{array}$ & $\begin{array}{l}-0.0135 \\
(0.0017)^{* *}\end{array}$ & $\begin{array}{l}-0.0172 \\
(0.0035)^{* *}\end{array}$ & $\begin{array}{l}-0.0127 \\
(0.0019)^{* *}\end{array}$ \\
\hline Rural location & $\begin{array}{l}-0.05 \\
(0.0035)^{* *}\end{array}$ & $\begin{array}{l}-0.0496 \\
(0.0037)^{* *}\end{array}$ & $\begin{array}{l}-0.0482 \\
(0.0039)^{* *}\end{array}$ & $\begin{array}{l}-0.0489 \\
(0.0042)^{* *}\end{array}$ & $\begin{array}{l}-0.0092 \\
(0.0059)\end{array}$ & $\begin{array}{l}-0.0526 \\
(0.0047)^{* *}\end{array}$ \\
\hline Municipality \% of full-time high schools & & & $\begin{array}{l}-0.0011 \\
(0.0053)\end{array}$ & $\begin{array}{l}-0.0038 \\
(0.0079)\end{array}$ & $\begin{array}{l}-0.0052 \\
(0.0094)\end{array}$ & $\begin{array}{l}-0.0042 \\
(0.0092)\end{array}$ \\
\hline Municipality mean education (years) & & & $\begin{array}{l}0.006 \\
(0.0021)^{* *}\end{array}$ & $\begin{array}{l}0.0112 \\
(0.0047)^{*}\end{array}$ & $\begin{array}{l}0.0076 \\
(0.0047)\end{array}$ & $\begin{array}{l}0.0094 \\
(0.0058)\end{array}$ \\
\hline Municipality unemployment rate (\%) & & & $\begin{array}{l}-0.0008 \\
(0.0005)\end{array}$ & $\begin{array}{l}-0.0014 \\
(0.0007)^{*}\end{array}$ & $\begin{array}{l}0.0001 \\
(0.0006)\end{array}$ & $\begin{array}{l}-0.0018 \\
(0.0008)^{*}\end{array}$ \\
\hline Municipality mean income (autonomous) & & & $\begin{array}{l}-0.0185 \\
(0.0067)^{* *}\end{array}$ & $\begin{array}{l}-0.0101 \\
(0.0111)\end{array}$ & $\begin{array}{l}0.005 \\
(0.0118)\end{array}$ & $\begin{array}{l}-0.0161 \\
(0.0146)\end{array}$ \\
\hline Municipality characteristics & NO & NO & YES & YES & YES & YES \\
\hline Municipality fixed effects & NO & NO & NO & YES & YES & YES \\
\hline Observations & 62,880 & 52,327 & 52,327 & 52,327 & 13,704 & 38,623 \\
\hline R-squared & 0.52 & 0.48 & 0.48 & 0.48 & 0.29 & 0.48 \\
\hline Mean - Dependent Var.(observed) & 0.795 & 0.8402 & 0.8402 & 0.8402 & 0.9676 & 0.795 \\
\hline
\end{tabular}

(1) Includes all adolescent girls aged 15-19 years.(2)-(6) include adolescent girls living with their mothers. Robust standard errors in parentheses. * significant at 5\%; ** significant at $1 \%$. Not shown: constant, region-year and municipality fixed effects. Number of clusters $=332$. Household density $=$ number of persons/number of bedrooms in hhold. 


\section{Table 6. Adolescent motherhood effects on Schooling - OLS and IV results}

\begin{tabular}{|c|c|c|c|c|c|}
\hline $\begin{array}{l}\text { Dependent variable: Adolescent } \\
\text { attends or completed high school }\end{array}$ & $\begin{array}{l}(1) \\
\text { OLS }\end{array}$ & $\begin{array}{c}(2) \\
\text { IV-1 }\end{array}$ & $\begin{array}{c}(3) \\
\text { IV-2 }\end{array}$ & $\begin{array}{c}(4) \\
\text { IV-2B }\end{array}$ & $\begin{array}{c}(5) \\
\text { IV-3 }\end{array}$ \\
\hline Adolescent is a mother & $\begin{array}{l}-0.3075 \\
(0.0074)^{* *}\end{array}$ & $\begin{array}{l}-0.2132 \\
(0.4935)\end{array}$ & $\begin{array}{l}-0.2587 \\
(0.4916)\end{array}$ & $\begin{array}{l}-0.1738 \\
(0.4908)\end{array}$ & $\begin{array}{l}-0.201 \\
(0.4894)\end{array}$ \\
\hline Age & $\begin{array}{l}-0.0902 \\
(0.0014)^{* *}\end{array}$ & $\begin{array}{l}-0.0946 \\
(0.0235)^{* *}\end{array}$ & $\begin{array}{l}-0.0925 \\
(0.0234)^{* *}\end{array}$ & $\begin{array}{l}-0.0965 \\
(0.0233)^{* *}\end{array}$ & $\begin{array}{l}-0.0952 \\
(0.0233)^{* *}\end{array}$ \\
\hline Schooling (years) & $\begin{array}{l}0.1025 \\
(0.0015)^{* *}\end{array}$ & $\begin{array}{l}0.1044 \\
(0.0102)^{* *}\end{array}$ & $\begin{array}{l}0.1035 \\
(0.0102)^{* *}\end{array}$ & $\begin{array}{l}0.1052 \\
(0.0101)^{* *}\end{array}$ & $\begin{array}{l}0.1046 \\
(0.0101)^{* *}\end{array}$ \\
\hline Num. Elderly (65yrs+) & $\begin{array}{l}0.0102 \\
(0.0029)^{* *}\end{array}$ & $\begin{array}{l}0.012 \\
(0.0097)\end{array}$ & $\begin{array}{l}0.0111 \\
(0.0096)\end{array}$ & $\begin{array}{l}0.0127 \\
(0.0096)\end{array}$ & $\begin{array}{l}0.0122 \\
(0.0096)\end{array}$ \\
\hline Num.children aged 6-14 & $\begin{array}{l}-0.0037 \\
(0.0018)^{*}\end{array}$ & $\begin{array}{l}-0.0029 \\
(0.0042)\end{array}$ & $\begin{array}{l}-0.0033 \\
(0.0042)\end{array}$ & $\begin{array}{l}-0.0026 \\
(0.0042)\end{array}$ & $\begin{array}{l}-0.0028 \\
(0.0042)\end{array}$ \\
\hline Female-headed hhold & $\begin{array}{l}-0.0103 \\
(0.0033)^{* *}\end{array}$ & $\begin{array}{l}-0.0123 \\
(0.0112)\end{array}$ & $\begin{array}{l}-0.0113 \\
(0.0111)\end{array}$ & $\begin{array}{l}-0.0131 \\
(0.0111)\end{array}$ & $\begin{array}{l}-0.0125 \\
(0.0111)\end{array}$ \\
\hline Education-head of hhold (years) & $\begin{array}{l}0.005 \\
(0.0004)^{* *}\end{array}$ & $\begin{array}{l}0.005 \\
(0.0004)^{* *}\end{array}$ & $\begin{array}{l}0.005 \\
(0.0004)^{* *}\end{array}$ & $\begin{array}{l}0.005 \\
(0.0004)^{* *}\end{array}$ & $\begin{array}{l}0.005 \\
(0.0004)^{* *}\end{array}$ \\
\hline Hhold income/capita & $\begin{array}{l}0.0029 \\
(0.0009)^{* *}\end{array}$ & $\begin{array}{l}0.0032 \\
(0.0020)\end{array}$ & $\begin{array}{l}0.003 \\
(0.0020)\end{array}$ & $\begin{array}{l}0.0033 \\
(0.0020)\end{array}$ & $\begin{array}{l}0.0032 \\
(0.0020)\end{array}$ \\
\hline Hhold density & $\begin{array}{l}-0.0135 \\
(0.0017)^{* *}\end{array}$ & $\begin{array}{l}-0.0159 \\
(0.0128)\end{array}$ & $\begin{array}{l}-0.0148 \\
(0.0128)\end{array}$ & $\begin{array}{l}-0.017 \\
(0.0127)\end{array}$ & $\begin{array}{l}-0.0163 \\
(0.0127)\end{array}$ \\
\hline Rural location & $\begin{array}{l}-0.0489 \\
(0.0042)^{* *}\end{array}$ & $\begin{array}{l}-0.0478 \\
(0.0058)^{* *}\end{array}$ & $\begin{array}{l}-0.0482 \\
(0.0058)^{* *}\end{array}$ & $\begin{array}{l}-0.0474 \\
(0.0058)^{* *}\end{array}$ & $\begin{array}{l}-0.0477 \\
(0.0058)^{* *}\end{array}$ \\
\hline Municipality \% full-time high schools & $\begin{array}{l}-0.0038 \\
(0.0079)\end{array}$ & $\begin{array}{l}-0.0037 \\
(0.0092)\end{array}$ & $\begin{array}{l}-0.0043 \\
(0.0092)\end{array}$ & $\begin{array}{l}-0.0032 \\
(0.0092)\end{array}$ & $\begin{array}{l}-0.0036 \\
(0.0092)\end{array}$ \\
\hline Municipality mean education (years) & $\begin{array}{l}0.0112 \\
(0.0047)^{*}\end{array}$ & $\begin{array}{l}0.011 \\
(0.0041)^{* *}\end{array}$ & $\begin{array}{l}0.011 \\
(0.0041)^{* *}\end{array}$ & $\begin{array}{l}0.011 \\
(0.0041)^{* *}\end{array}$ & $\begin{array}{l}0.011 \\
(0.0041)^{* *}\end{array}$ \\
\hline Municipality unemployment rate (\%) & $\begin{array}{l}-0.0014 \\
(0.0007)^{*}\end{array}$ & $\begin{array}{l}-0.0013 \\
(0.0006)^{*}\end{array}$ & $\begin{array}{l}-0.0013 \\
(0.0006)^{*}\end{array}$ & $\begin{array}{l}-0.0013 \\
(0.0006)^{*}\end{array}$ & $\begin{array}{l}-0.0013 \\
(0.0006)^{*}\end{array}$ \\
\hline Municipality mean income & $\begin{array}{l}-0.0101 \\
(0.0111)\end{array}$ & $\begin{array}{l}-0.0109 \\
(0.0098)\end{array}$ & $\begin{array}{l}-0.0106 \\
(0.0098)\end{array}$ & $\begin{array}{l}-0.0111 \\
(0.0098)\end{array}$ & $\begin{array}{l}-0.0109 \\
(0.0098)\end{array}$ \\
\hline Instruments & n.a. & Teen Mom2 & \multicolumn{3}{|c|}{ TeenBirthRate UnwedBirthRate } \\
\hline Observations $\left(\mathrm{R}^{2}\right)$ & $52,327(0.48)$ & 52,327 & 52,327 & 52,327 & 52,327 \\
\hline Mean - Dependent Var. (observed) & 0.8402 & 0.84 & 0.84 & 0.84 & 0.84 \\
\hline F-test of instruments in 1st stage & & 0.025 & 0.079 & 0.076 & 0.161 \\
\hline Over-identification test & & n.a. & 0.065 & 0.515 & 0.109 \\
\hline $\begin{array}{l}\text { DWH Test of exogeneity: } \\
\beta_{\text {OLS }}=\beta_{\mathrm{IV}} \text { (P-value) }\end{array}$ & & 0.931 & 0.841 & 0.744 & 0.744 \\
\hline
\end{tabular}

Robust standard errors in parentheses. * significant at 5\%; ** significant at 1\%. Includes adolescent girls aged 15-19 years that live with their mother. OLS results are from column (4) of Table 5. Not shown: constant, region-year and municipality fixed effects. Number of clusters $=332$. Household density $=$ number of persons/number of bed.

TeenMom ${ }^{2}=$ adolescent's mother was also an adolescent mom. DWH=Durbin-Wu-Hausman test. 
Table 7. Adolescent motherhood effects on Schooling, 1990-2006 (OLS)

\begin{tabular}{|c|c|c|c|c|c|c|c|c|}
\hline $\begin{array}{l}\text { Dependent variable: } \\
\text { Teen is enrolled or } \\
\text { completed HS }\end{array}$ & $\begin{array}{r}(1) \\
1990\end{array}$ & $\begin{array}{c}(2) \\
1992\end{array}$ & $\begin{array}{r}(3) \\
1994\end{array}$ & $\begin{array}{r}(4) \\
1996 \\
\end{array}$ & $\begin{array}{r}(5) \\
1998\end{array}$ & $\begin{array}{r}(6) \\
2000\end{array}$ & $\begin{array}{r}(7) \\
2003\end{array}$ & $\begin{array}{r}(8) \\
2006 \\
\end{array}$ \\
\hline Teen is & $\begin{array}{l}-0.4119 \\
(0.0301)^{* *}\end{array}$ & $\begin{array}{l}-0.3416 \\
(0.0220)^{* *}\end{array}$ & $\begin{array}{l}-0.3328 \\
(0.0238)^{* *}\end{array}$ & $\begin{array}{l}-0.3521 \\
(0.0253)^{* *}\end{array}$ & $\begin{array}{l}-0.2718 \\
(0.0196)^{* *}\end{array}$ & $\begin{array}{l}-0.3083 \\
(0.0168)^{* *}\end{array}$ & $\begin{array}{l}-0.2855 \\
(0.0159)^{* *}\end{array}$ & $\begin{array}{l}-0.302 \\
(0.017)^{*}\end{array}$ \\
\hline Obser & 2,875 & 4,398 & 5,697 & 4,150 & 6,484 & 8,838 & 9,301 & 10,584 \\
\hline $\begin{array}{l}\text { R-squared } \\
\text { Mean Dep Var } \\
\text { (observed) }\end{array}$ & $\begin{array}{l}0.52 \\
0.813 \\
\end{array}$ & $\begin{array}{l}0.5 \\
0.776 \\
\end{array}$ & $\begin{array}{l}0.53 \\
0.764 \\
\end{array}$ & $\begin{array}{l}0.5 \\
0.815 \\
\end{array}$ & $\begin{array}{l}0.51 \\
0.827 \\
\end{array}$ & $\begin{array}{l}0.5 \\
0.834 \\
\end{array}$ & $\begin{array}{l}0.48 \\
0.881 \\
\end{array}$ & $\begin{array}{l}0.42 \\
0.903 \\
\end{array}$ \\
\hline
\end{tabular}

Robust standard errors in parentheses. Not shown: region-year and muncipality fixed effects. * significant at 5\%; ** significant at $1 \%$. Household density=number of persons/number of bedrooms in hhold. 